Asian-Australasian Journal of

Bioscience and Biotechnology

ISSN 2414-1283 (Print) 2414-6293 (Online)

www.ebupress.com/journal/aajbb

\title{
Article \\ Estimation of residue degradation of cypermethrin and chlorpyrifos in brinjal, tomato and cauliflower under supervised field trial
}

Md. Sultan Ahmed*, Mohammad Dalower Hossain Prodhan, Afroza Begum, Marina Afroze and Debasish Sarker

Division of Entomology, Bangladesh Agricultural Research Institute, Joydebpur, Gazipur-1701, Bangladesh

*Corresponding author: Md. Sultan Ahmed, Division of Entomology, Bangladesh Agricultural Research Institute, Joydebpur, Gazipur-1701, Bangladesh. E-mail: sultan_palbari@yahoo.com

Received: 16 June 2021/Accepted: 10 August 2020/ Published: 31 August 2021

\begin{abstract}
A study was carried out to detect and estimate the residue of cypermethrin and chlorpyrifos in brinjal, tomato and cauliflower using Gas Chromatography (GC) coupled with Electron Capture Detector (ECD) and Flame Thermionic Detector (FTD). Three supervised field trials were conducted and sprayed with the recommended dose of cypermethrin ( $1 \mathrm{ml} / \mathrm{L}$ of water) and chlorpyrifos $(3 \mathrm{ml} / \mathrm{L}$ of water) in three vegetables by knapsack sprayer. Samples were collected at 0, 1, 2, 3, 4, 5, 6, 7, 8, 9, 10, and 11 days after spray (DAS). The quantity of cypermethrin residue was above EU-MRLs (Maximum Residue Limit set by European Union) up to 4 DAS with $0.538 \mathrm{mg} / \mathrm{kg}$ in cauliflower; 3 DAS with $0.508 \mathrm{mg} / \mathrm{kg}$ in brinjal and $0.695 \mathrm{mg} / \mathrm{kg}$ in tomato. The quantity decreased down $0.328-0.019 \mathrm{mg} / \mathrm{kg}$ in cauliflower (4-9 DAS); $0.098-0.012 \mathrm{mg} / \mathrm{kg}$ (4-7 DAS) in brinjal and $0.458-0.022 \mathrm{mg} / \mathrm{kg}$ (4-7 DAS) in tomato which were below EU-MRLs $(0.5 \mathrm{mg} / \mathrm{kg})$. The quantity of chlorpyrifos residue was above EU-MRLs up to 9 DAS with $0.012 \mathrm{mg} / \mathrm{kg}$ in cauliflower but in brinjal and tomato, the detected quantities were above EU-MRLs up to 7 DAS with $0.029 \mathrm{mg} / \mathrm{kg}$ and $0.017 \mathrm{mg} / \mathrm{kg}$ residue. No residue was detected from brinjal and tomato samples collected at 8 DAS. But in cauliflower, no residue was detected at 10 days after spray. So, brinjal, tomato and cauliflower can be harvested safely at 4 DAS and 5 DAS for cypermethrin and in case of chlorpyrifos it was 8 DAS in brinjal and tomato and 10 DAS in cauliflower.
\end{abstract}

Keywords: residue; degradation; chlorpyrifos; cypermethrin; MRL; gas chromatography

\section{Introduction}

Cauliflower, brinjal and tomato are rich in vitamins and minarals and consumers of Bangladesh are well-liked. At present, quality and safe food production is a public demand in Bangladesh. But vegetable productions are seriously hampered by the attack of insect pests. Brinjal, cauliflower and tomato are attacked by a variety of insect pests (Nayar et al., 1994; Rekha and Mallapur, 2007; Riley and Sparks, 2008). The farmers of Bangladesh spray pesticides as a major component of plant protection because of its small quantity in packaging, storage facility at nomal temperature and availability in the market. The pattern of insecticide usage in vegetables led to assume that major vegetable growing areas of Bangladesh should be overloaded with pesticide residue, since pesticides are being used by farmers whimsically. It was understood from farmers' interview that they use insecticides indiscriminately. Most of the commercial farmers sell vegetables at an interval of 0-2 days after spray (Anon, 2001; Ahmed et al., 2005). It was reported that over-sprayed vegetable consumers might face health hazards and environment might be over loaded with pesticide residue. Synthetic toxic pesticide can become hazard to the public and the environment. Pesticide can produce negative impacts, both social and private (Antle and Pingali, 1994). Some of the acute and chronic human illnesses have now emerged as a consequence of intake of polluted water, air or food (Gill and Garg, 2014). There is a link between pesticides 
exposure and the incidences of human chronic diseases affecting nervous, reproductive, renal, cardiovascular, and respiratory systems (Mostafalou and Abdollahi, 2012).

In Bangladesh, most of the vegetable growers do not follow the prescribed dosages and use pesticides at any stage of the crop without maintaining waiting period. By this time, the pesticide residues get dissipated of its abuse. It is noted that food products become safe for consumption only after withholding period has lapsed. The monitoring of pesticide residue mainly in vegetables was done in regular basis in many countries (Van der Schee, 2002; Kumar et al., 2004; Rajeshwaran et al., 2004, Ahmed et al., 2016a; Ahmed et al., 2018a; Ahmed et al., 2019; Ahmed et al., 2021). The extent and rate of dissipation depends on the nature of the pesticide, crop, cultural practices and various environmental conditions under which the crop is grown or a treated commodity is stored (Handa et al., 1999). There are very scanty references in pesticide degradation rate in vegetables in Bangladesh (Ahmed et al., 2018b, Prodhan et al., 2018; Ahmed et al., 2020). Considering these, the present study was carried out to estimate the amount and degradation rate of residue of two commonly used insecticides in brinjal, tomato and cauliflower.

\section{Materials and Methods}

The present study was conducted at Pesticide Analytical Laboratory and field of Entomology Division, Bangladesh Agricultural Research Institute Gazipur (BARI). The insecticide standard for chlorpyrifos and cypermethrin were obtained from Sigma-Aldrich Laborchemikalien, Gmbh P O Box-100262 D-30918, Seelze, Germany via Bangladesh Scientific Pvt. Itd. Dhaka, Bangladesh. Standards of chlorpyrifos contained 99.3\% purity and cypermethrin had $98 \%$ purity. Marketable size of brinjal, tomato and cauliflower were collected from three different supervised field trials at $0,1,2,3,4,5,6,7,8,9,10$ and 11 days after spray (DAS) which were sprayed with chlorpyrifos @ $3 \mathrm{~mL}$ per litre of water and cypermethrin @ $1 \mathrm{ml} / \mathrm{L}$ of water by knapsack sprayer. The formulated products of those were Dursban 20EC and Cymbush 10EC. The purity of formulated brand of both the insecticides were tested in the Pesticide Analytical Laboratory and found 100\% pure.

\subsection{Sample extraction, separation and clean up}

The sample extraction technique was used prescribed by William and George (2005) that was adopted with little modifications. Collected samples $(\geq 250 \mathrm{~g})$ were chapped and grounded thoroughly with the meat grinder (Handmixer M-122, Bamix, Switzerland). A sub sample of $20 \mathrm{~g}$ was taken into a wide mouth jar then $100 \mathrm{~mL}$ of hexane was added to it. Sodium sulphate $\left(\mathrm{Na}_{2} \mathrm{SO}_{4}\right)$ was also added with sample until water was removed from the sample. The mixture was then macerated with high-speed homogenizer (Ultraturax, IKA T18 basic, Germany) for 2 minutes. The homogenized material was then poured into $250 \mathrm{~mL}$ conical flask and placed into the shaker (Orbital Shaking Incubator, Rexmed, Sweden) for $12 \mathrm{hrs}$ continuous shaking. After shaking, the slurry was filtered through a Buchner funnel with suction. The flask and filter cakes were rinsed with $25 \mathrm{~mL}$ of hexane each. The filtrate was then transferred into $250 \mathrm{~mL}$ round bottom flask and was dried to $5 \mathrm{~mL}$ by evaporation using a rotary vacuum evaporator (Laborota-4001, Heidolph, Germany). The concentrated filtrate was then transferred into $500 \mathrm{~mL}$ separatory funnel making $10 \mathrm{~mL}$ in volume. Around $20 \mathrm{~mL}$ methanol was added with $10 \mathrm{~mL}$ filtrate and shaked vigorously for 5 minutes. After shaking, the separatory funnel was set on stand and kept undisturbed for 5 minutes. Then the clear part of the solution from the bottom of the separatory funnel was collected in a vial which was then centrifuged at $1200 \mathrm{rpm}$ for 5 minutes (Laboratory Centrifuges, Sigma-3K30, Germany). After centrifuge, supernatant was collected for injection in Gas Chromatography.

\subsection{Detection and estimation of pesticide residue in samples}

The concentrated extracts were subjected to analysis by GC-2010 (Shimadzu). Flame Therm ionic Detector (FTD) was used for the detection of chlorpyrifos and the Electron Capture Detector (ECD) was used for the detection of cypermethrin. The capillary column used in FTD was ATTM-1, length 30m, Inner Diameter (ID) $0.25 \mathrm{~mm}$ and film thickness $0.25 \mu \mathrm{m}$ and in case of ECD it was Optima 1 and length, ID and film thickness was same. Nitrogen was used as carrier and make up gas in ECD and in FTD it was Helium. The instrument parameters for detecting chlorpyrifos and cypermethrin were in Table 1. 
Table 1. The instrument parameters for GC-FTD and GC-ECD.

\begin{tabular}{lll}
\hline Instrument parameters & Chlorpyrifos & Cypermethrin \\
\hline Instrument & GC-2010 & GC-2010 \\
[Injection Port SPL] & & \\
Injector (Auto) & AOC 20i & AOC $20 \mathrm{i}$ \\
Injection Mode & Split & Split \\
Temperature & $250^{\circ} \mathrm{C}$ & $280^{\circ} \mathrm{C}$ \\
Flow Control Mode & Linear velocity & Linear velocity \\
Linear Velocity & $40.0 \mathrm{~cm} / \mathrm{sec}$ & $40.0 \mathrm{~cm} / \mathrm{sec}$ \\
Purge Flow & $3.0 \mathrm{ml} / \mathrm{min}$ & $3.0 \mathrm{ml} / \mathrm{min}$ \\
Split Ratio & 30.0 & 10.0 \\
Injection Volume & $2.0 \mu \mathrm{l}$ & $2.0 \mu \mathrm{l}$ \\
[Column Oven] & & \\
Column Oven Temperature Program: & & \\
Initial Temperature & $150^{\circ} \mathrm{C}$ & $160^{\circ} \mathrm{C}$ \\
Final Temperature & $220^{\circ} \mathrm{C}$ & $270^{\circ} \mathrm{C}$ \\
Equilibrium Time & $1.0 \mathrm{~min}, \mathrm{Hold}$ time: 2 & $1.0 \mathrm{~min}, \mathrm{Hold}$ time: 6 \\
Total Program Time & $10.0 \mathrm{~min}$ & $18.0 \mathrm{~min}$ \\
[Column Information] & & \\
Column Name & $\mathrm{ATTM}-1$ & $\mathrm{Optima}-1$ \\
Column Length & $30.0 \mathrm{~m}$ & $30.0 \mathrm{~m}$ \\
Film Thickness & $0.25 \mu \mathrm{m}$ & $0.25 \mu \mathrm{m}$ \\
Inner Diameter & $0.25 \mathrm{~mm}$ & $0.25 \mathrm{~mm}$ \\
[Detector Channel 1] & & \\
Detector & FTD & $\mathrm{ECD}$ \\
Temperature & $280^{\circ} \mathrm{C}$ & $300^{\circ} \mathrm{C}$ \\
Stop Time & $10.0 \mathrm{~min}$ & $18.0 \mathrm{~min}$ \\
Current & $1.0 \mathrm{pA}$ & $1.0 \mathrm{pA}$ \\
Makeup Flow & $30.0 \mathrm{ml} / \mathrm{min}$ & $30.0 \mathrm{ml} / \mathrm{min}$ \\
$\mathrm{H}_{2}$ Flow & $1.5 \mathrm{ml} / \mathrm{min}$ & - \\
Air Flow & $145.0 \mathrm{ml} / \mathrm{min}$ & - \\
\hline
\end{tabular}

Prior to the injection of the sample extract, standard solutions of different concentrations of both insecticides were prepared and injected with the above instrument parameters. The samples were calibrated (retention time, peak area etc.) against four pointed calibration curve of standard solution of concerned pesticide. Each peak was characterized by its retention time. Sample results were expressed in $\mathrm{mg} / \mathrm{kg}$ automatically by the GC software which represented the concentration of the final volume injected. From this value the actual amount of insecticide residue present in the sample was determined by using the following formula.

Conc. obtained in injected volume $(\mathrm{mg} / \mathrm{kg}) \mathrm{X}$ Quantity of final volume $(\mathrm{L})$

Residue in sample $(\mathrm{mg} / \mathrm{kg})=$

\section{Results}

The brinjal, cauliflower and tomato samples containing chlorpyrifos residues were analyzed using GC-FTD with set parameters and for the detection of cypermethrin residue, it was GC-ECD. The results obtained from this analysis have been summarized in Table 2-7. 
Table 2. Quantity of residue of cypermethrin (Cymbush 10EC) estimated from brinjal.

\begin{tabular}{ccccccc}
\hline $\begin{array}{c}\text { Days after } \\
\text { spraying }\end{array}$ & $\begin{array}{c}\text { Sample } \\
\text { weight } \\
(\mathbf{g})\end{array}$ & $\begin{array}{c}\text { Total volume } \\
\text { prepared } \\
(\mathbf{m l})\end{array}$ & $\begin{array}{c}\text { Injected } \\
\text { volume } \\
(\boldsymbol{\mu l})\end{array}$ & $\begin{array}{c}\text { Concentration } \\
\text { obtained in final } \\
\text { volume }(\mathbf{m g} / \mathbf{k g})\end{array}$ & $\begin{array}{c}\text { Amount of } \\
\text { residue } \\
(\mathbf{m g} / \mathbf{k g})\end{array}$ & $\begin{array}{c}\text { EU MRL } \\
(\mathbf{m g} / \mathbf{k g})\end{array}$ \\
\hline 0 & 20 & 10 & 2 & 3.144 & 1.572 & 0.5 \\
1 & 20 & 10 & 2 & 1.646 & 0.823 & \\
2 & 20 & 10 & 2 & 1.308 & 0.654 & \\
3 & 20 & 10 & 2 & 1.016 & 0.508 & \\
4 & 20 & 10 & 2 & 0.196 & 0.098 & \\
5 & 20 & 10 & 2 & 0.114 & 0.057 & \\
6 & 20 & 10 & 2 & 0.050 & 0.025 & \\
7 & 20 & 10 & 2 & 0.024 & 0.012 & \\
8 & 20 & 10 & 2 & ND & ND & \\
\hline
\end{tabular}

Residue of cypermethrin in brinjal was detected up to 7 DAS and the quantities were above EU-MRL up to 3 DAS and these were $1.572 \mathrm{mg} / \mathrm{kg}, 0.823 \mathrm{mg} / \mathrm{kg}, 0.654 \mathrm{mg} / \mathrm{kg}$ and $0.508 \mathrm{mg} / \mathrm{kg}$ at $0,1,2$ and 3 DAS, respectively. Samples of 4 to 7 DAS contained $0.098-0.012 \mathrm{mg} / \mathrm{kg}$ residues which are below MRL set by European Union. No residue was detected at 8 DAS.

Table 3. Quantity of residue of cypermethrin (Cymbush 10EC) estimated from cauliflower.

\begin{tabular}{ccccccc}
\hline $\begin{array}{c}\text { Days after } \\
\text { spraying }\end{array}$ & $\begin{array}{c}\text { Sample } \\
\text { weight } \\
(\mathbf{g})\end{array}$ & $\begin{array}{c}\text { Total volume } \\
\text { prepared } \\
(\mathbf{m l})\end{array}$ & $\begin{array}{c}\text { Injected } \\
\text { volume } \\
(\boldsymbol{\mu l})\end{array}$ & $\begin{array}{c}\text { Concentration } \\
\text { obtained in final } \\
\text { volume }(\mathbf{m g} / \mathbf{k g})\end{array}$ & $\begin{array}{c}\text { Amount of } \\
\text { residue } \\
(\mathbf{m g} / \mathbf{k g})\end{array}$ & $\begin{array}{c}\text { EU MRL } \\
(\mathbf{m g} / \mathbf{k g})\end{array}$ \\
\hline 0 & 20 & 10 & 2 & 5.604 & 2.802 & 0.5 \\
1 & 20 & 10 & 2 & 2.610 & 1.305 & \\
2 & 20 & 10 & 2 & 1.884 & 0.942 & \\
3 & 20 & 10 & 2 & 1.468 & 0.734 & \\
4 & 20 & 10 & 2 & 1.076 & 0.538 \\
5 & 20 & 10 & 2 & 0.656 & 0.328 \\
6 & 20 & 10 & 2 & 0.402 & 0.201 \\
7 & 20 & 10 & 2 & 0.274 & 0.137 & \\
8 & 20 & 10 & 2 & 0.102 & 0.051 & \\
9 & 20 & 10 & 2 & 0.038 & 0.019 & \\
10 & 20 & 10 & 2 & ND & ND & \\
\hline
\end{tabular}

Residue of cypermethrin was detected up to 9 DAS in cauliflower. The detected quantities were above EU-MRL up to 4 DAS and these were $2.802 \mathrm{mg} / \mathrm{kg}, 1.305 \mathrm{mg} / \mathrm{kg}, 0.942 \mathrm{mg} / \mathrm{kg} 0.734 \mathrm{mg} / \mathrm{kg}$ and $0.538 \mathrm{mg} / \mathrm{kg}$ at $0,1,2,3$ and 4 DAS, respectively. While samples of 5 to 9 DAS contained residues $0.328-0.019 \mathrm{mg} / \mathrm{kg}$ which were below MRL set by European Union. No residue was detected at 10 DAS.

Table 4. Quantity of residue of cypermethrin (Cymbush 10EC) estimated from tomato.

\begin{tabular}{ccccccc}
\hline $\begin{array}{c}\text { Days after } \\
\text { spraying }\end{array}$ & $\begin{array}{c}\text { Sample } \\
\text { weight } \\
(\mathbf{g})\end{array}$ & $\begin{array}{c}\text { Total volume } \\
\text { prepared } \\
(\mathbf{m l})\end{array}$ & $\begin{array}{c}\text { Injected } \\
\text { volume }(\boldsymbol{\mu l})\end{array}$ & $\begin{array}{c}\text { Concentration } \\
\text { obtained in final } \\
\text { volume }(\mathbf{m g} / \mathbf{k g})\end{array}$ & $\begin{array}{c}\text { Amount of } \\
\text { residue } \\
(\mathbf{m g} / \mathbf{k g})\end{array}$ & $\begin{array}{c}\mathbf{E U ~ M R L} \\
(\mathbf{m g} / \mathbf{k g})\end{array}$ \\
\hline 0 & 20 & 10 & 2 & 5.964 & 2.982 & 0.50 \\
1 & 20 & 10 & 2 & 3.452 & 1.726 & \\
2 & 20 & 10 & 2 & 1.934 & 0.967 & \\
3 & 20 & 10 & 2 & 1.390 & 0.695 & \\
4 & 20 & 10 & 2 & 0.916 & 0.458 & \\
5 & 20 & 10 & 2 & 0.178 & 0.089 \\
6 & 20 & 10 & 2 & 0.094 & 0.047 & \\
7 & 20 & 10 & 2 & 0.044 & 0.022 & \\
8 & 20 & 10 & 2 & ND & ND & \\
\hline
\end{tabular}


The results revealed that residue of cypermethrin could be detected up to7 DAS in tomato. The quantities of residue were above EU-MRL up to 3 DAS and these were $2.982 \mathrm{mg} / \mathrm{kg}, 1.726 \mathrm{mg} / \mathrm{kg}, 0.967 \mathrm{mg} / \mathrm{kg}$ and 0.695 $\mathrm{mg} / \mathrm{kg}$ at $0,1,2$ and 3 DAS, respectively. While sample of 4 DAS to 7 DAS contained $0.458 \mathrm{mg} / \mathrm{kg}$ to 0.022 $\mathrm{mg} / \mathrm{kg}$ cypermithrin residue which were below MRL set by European Union. No residue was detected at 8 DAS.

Table 5. Quantity of residue of chlorpyrifos (Dursban 20EC) estimated from brinjal.

\begin{tabular}{ccccccc}
\hline $\begin{array}{c}\text { Days after } \\
\text { spraying }\end{array}$ & $\begin{array}{c}\text { Sample } \\
\text { weight } \\
(\mathbf{g})\end{array}$ & $\begin{array}{c}\text { Total volume } \\
\text { prepared } \\
(\mathbf{m l})\end{array}$ & $\begin{array}{c}\text { Injected } \\
\text { volume }(\boldsymbol{\mu l})\end{array}$ & $\begin{array}{c}\text { Concentration } \\
\text { obtained in final } \\
\text { volume }(\mathbf{m g} / \mathbf{k g})\end{array}$ & $\begin{array}{c}\text { Amount of } \\
\text { residue } \\
(\mathbf{m g} / \mathbf{k g})\end{array}$ & $\begin{array}{c}\mathbf{E U ~ M R L} \\
(\mathbf{m g} / \mathbf{k g})\end{array}$ \\
\hline 0 & 20 & 10 & 2 & 2.784 & 1.392 & 0.01 \\
1 & 20 & 10 & 2 & 1.462 & 0.731 & \\
2 & 20 & 10 & 2 & 1.034 & 0.517 & \\
3 & 20 & 10 & 2 & 0.784 & 0.392 & \\
4 & 20 & 10 & 2 & 0.422 & 0.211 & \\
5 & 20 & 10 & 2 & 0.234 & 0.117 & \\
6 & 20 & 10 & 2 & 0.134 & 0.067 & \\
7 & 20 & 10 & 2 & 0.058 & 0.029 & \\
8 & 20 & 10 & 2 & ND & ND & \\
\hline
\end{tabular}

The left over residue of chlorpyrifos in brinjal had been detected up to 7 DAS. The quantities of residues were $1.392 \mathrm{mg} / \mathrm{kg}, 0.731 \mathrm{mg} / \mathrm{kg}, 0.517 \mathrm{mg} / \mathrm{kg}, 0.392 \mathrm{mg} / \mathrm{kg}$ and $0.211 \mathrm{mg} / \mathrm{kg} 0.117 \mathrm{mg} / \mathrm{kg}, 0.067 \mathrm{mg} / \mathrm{kg}$ and 0.029 $\mathrm{mg} / \mathrm{kg}$ at $0,1,2,3,4,5,6$ and 7 DAS, respectively. All of the detected quantities $(1.392-0.029 \mathrm{mg} / \mathrm{kg}) \mathrm{of}$ residues were above MRL set by European Union. No residue was detected at 8 DAS.

Table 6. Quantity of residue of chlorpyrifos (Dursban 20EC) estimated from cauliflower.

\begin{tabular}{ccccccc}
\hline $\begin{array}{c}\text { Days after } \\
\text { spraying }\end{array}$ & $\begin{array}{c}\text { Sample } \\
\text { weight } \\
(\mathbf{g})\end{array}$ & $\begin{array}{c}\text { Total volume } \\
\text { prepared } \\
(\mathbf{m l})\end{array}$ & $\begin{array}{c}\text { Injected } \\
\text { volume }(\boldsymbol{\mu l})\end{array}$ & $\begin{array}{c}\text { Concentration } \\
\text { obtained in final } \\
\text { volume }(\mathbf{m g} / \mathbf{k g})\end{array}$ & $\begin{array}{c}\text { Amount of } \\
\text { residue } \\
(\mathbf{m g} / \mathbf{k g})\end{array}$ & $\begin{array}{c}\text { EU MRL } \\
(\mathbf{m g} / \mathbf{k g})\end{array}$ \\
\hline 0 & 20 & 10 & 2 & 3.062 & 1.531 & 0.01 \\
1 & 20 & 10 & 2 & 1.874 & 0.937 & \\
2 & 20 & 10 & 2 & 1.622 & 0.811 & \\
3 & 20 & 10 & 2 & 1.264 & 0.632 & \\
4 & 20 & 10 & 2 & 0.956 & 0.478 & \\
5 & 20 & 10 & 2 & 0.602 & 0.301 & \\
6 & 20 & 10 & 2 & 0.394 & 0.197 & \\
7 & 20 & 10 & 2 & 0.098 & 0.049 & \\
8 & 20 & 10 & 2 & 0.054 & 0.027 & \\
9 & 20 & 10 & 2 & 0.024 & 0.012 & \\
10 & 20 & 10 & 2 & ND & ND & \\
\hline
\end{tabular}

Form the Table 6, it was observed that chlorpyrifos residue was detected in the cauliflower sample up to 9 DAS. The quantities of residues were $1.531 \mathrm{mg} / \mathrm{kg}, 0.937 \mathrm{mg} / \mathrm{kg}, 0.811 \mathrm{mg} / \mathrm{kg}, 0.632 \mathrm{mg} / \mathrm{kg}, 0.478 \mathrm{mg} / \mathrm{kg}, 0.301$ $\mathrm{mg} / \mathrm{kg}, 0.197 \mathrm{mg} / \mathrm{kg}, 0.049 \mathrm{mg} / \mathrm{kg}, 0.027 \mathrm{mg} / \mathrm{kg}$ and $0.012 \mathrm{mg} / \mathrm{kg}$ at $0,1,2,3,4,5,6,7,8$ and 9 DAS, respectively. All of the tested samples showed residues $(1.531-0.012 \mathrm{mg} / \mathrm{kg}$ ) which were above MRL set by European Union. At 10 DAS, no residue was detected. 
Table 7. Quantity of residue of chlorpyrifos (Dursban 20EC) estimated from tomato.

\begin{tabular}{ccccccc}
\hline $\begin{array}{c}\text { Days after } \\
\text { spraying }\end{array}$ & $\begin{array}{c}\text { Sample } \\
\text { weight } \\
(\mathbf{g})\end{array}$ & $\begin{array}{c}\text { Total volume } \\
\text { prepared } \\
(\mathbf{m l})\end{array}$ & $\begin{array}{c}\text { Injected } \\
\text { volume }(\boldsymbol{\mu l})\end{array}$ & $\begin{array}{c}\text { Concentration } \\
\text { obtained in final } \\
\text { volume }(\mathbf{m g} / \mathbf{k g})\end{array}$ & $\begin{array}{c}\text { Amount of } \\
\text { residue } \\
(\mathbf{m g} / \mathbf{k g})\end{array}$ & $\begin{array}{c}\mathbf{E U ~ M R L} \\
(\mathbf{m g} / \mathbf{k g})\end{array}$ \\
\hline 0 & 20 & 10 & 2 & 2.172 & 1.086 & 0.01 \\
1 & 20 & 10 & 2 & 1.474 & 0.737 & \\
2 & 20 & 10 & 2 & 1.284 & 0.642 & \\
3 & 20 & 10 & 2 & 1.026 & 0.513 & \\
4 & 20 & 10 & 2 & 0.958 & 0.479 & \\
5 & 20 & 10 & 2 & 0.266 & 0.133 \\
6 & 20 & 10 & 2 & 0.134 & 0.067 \\
7 & 20 & 10 & 2 & 0.034 & 0.017 & \\
8 & 20 & 10 & 2 & ND & ND & \\
\hline
\end{tabular}

The results revealed that residue of chlorpyrifos could be detected up to 7 DAS in tomato. The detected quantities were $1.086 \mathrm{mg} / \mathrm{kg}, 0.737 \mathrm{mg} / \mathrm{kg}, 0.642 \mathrm{mg} / \mathrm{kg}, 0.513 \mathrm{mg} / \mathrm{kg}, 0.479 \mathrm{mg} / \mathrm{kg} 0.133 \mathrm{mg} / \mathrm{kg}, 0.067 \mathrm{mg} / \mathrm{kg}$ and $0.017 \mathrm{mg} / \mathrm{kg}$ at $0,1,2,3,4,5,6$ and $7 \mathrm{DAS}$, respectively. All of the detected quantities (1.086- 0.017 $\mathrm{mg} / \mathrm{kg}$ ) of residues in tomato were above EU-MRL. No residue was detected at 8 DAS.

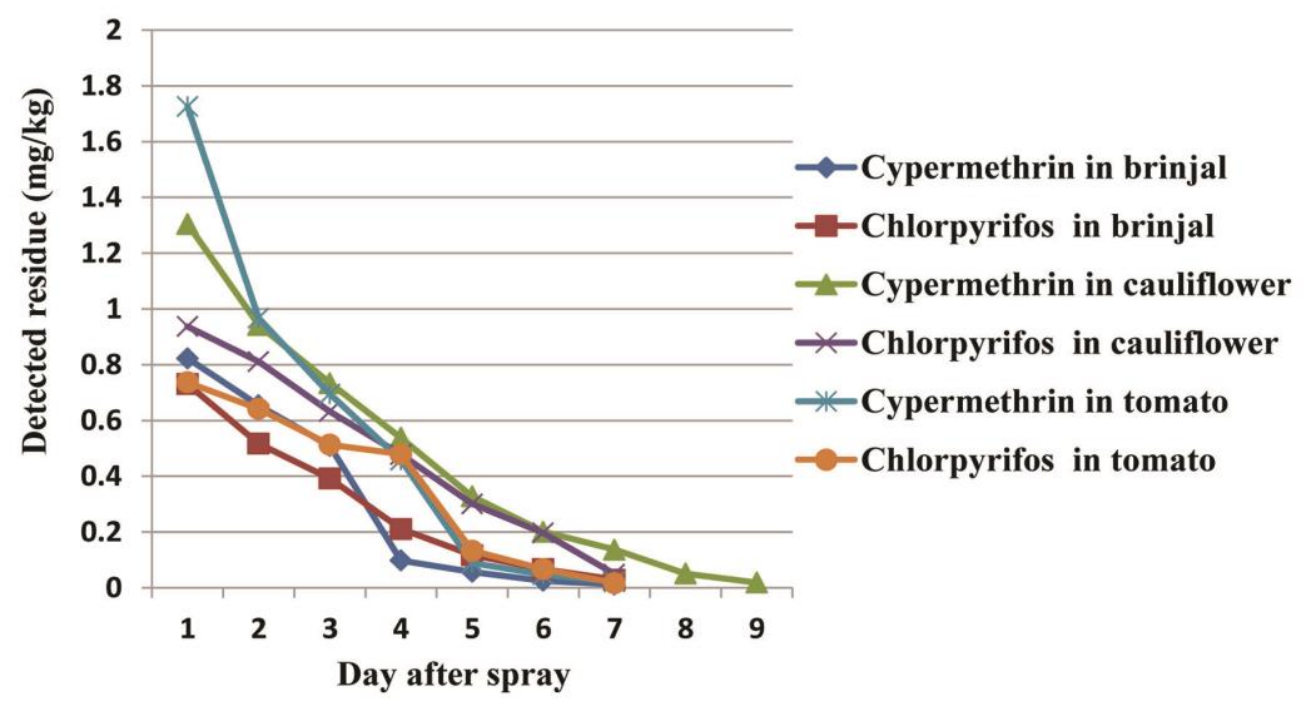

Figure 1. Degradation of cypermethrin and chlorpyrifos in brinjal, cauliflower and tomato over time.

The trends of degradation of detected residue of cypermethrin and chlorpyrifos in the samples of three different vegetables viz. brinjal, cauliflower and tomato over time are shown in Figure 1. From the figure it was observed that the degradation rate of chlorpyrifos was slow in all of the analyzed vegetables although their residue levels were above MRL up to 7 DAS in brinjal and tomato and 9 DAS in cauliflower. The rate of degradation of cypermethrin was faster than chlorpyrifos in all of the vegetables and the levels of their residues were below MRL up to 3 DAS in brinjal and tomato and 4 DAS in cauliflower.

\section{Discussion}

The results revealed that residue of cypermethrin was detected up to 7 DAS and the quantities were above MRL up to 3 DAS in brinjal and tomato. While for at 4 to 7 DAS the residue decreased down $0.098-0.012 \mathrm{mg} / \mathrm{kg}$ in brinjal and $0.458-0.022 \mathrm{mg} / \mathrm{kg}$ in tomato that were below MRL. But in cauliflower the residue of cypermethrin was detected up to 9 DAS and the quantities were above MRL up to 4 DAS. Samples of 5 to 9 DAS contained $0.328-0.019 \mathrm{mg} / \mathrm{kg}$ residues which were below MRL. Residue of chlorpyrifos was detected up to 7 DAS in brinjal and tomato and in case of cauliflower it was 9 DAS. All of the detected quantities of chlorpyrifos residues were above MRL in vegetables. The rate of degradation of the tested insecticides was varied among the three tested vegetables. The plant behavior might be related to physico-chemical properties of pesticides for example uptake by plants, metabolism, etc. (O' Brein, 1967; Virgina and Bajet, 1996). Tejada et al. (1983) reported that the disappearance of residue in and on plants is the effect of the interaction of environmental 
conditions such as the wind, rain, sun, humidity and temperature and chemical and physical factors such as volatilization and growth of the plant.

Agnihotri et al. (1990) and Singh and Kalra (1996) found detectable level of residue of cypermethrin and fenvalerate up to 7 days of spraying of recommended dose. Ahmed et al. (2016b) reported that acephate was detected up to 14 DAS in hyacinth bean and tomato which was the longer period of degradation than fenvalerate but their quantity were above MRL at 9 DAS in both the vegetables. For fenvalerate, the detected residue level was above MRL up to 3 DAS in hyacinth bean and tomato. Ahmed et al. (2020) found dimethoate residue was detected up to 11 DAS in cauliflower; 10 DAS in hyacinth bean and 9 DAS in eggplant which were longer period of degradation than quinalphos. The residue of quinalphos detected up to 9 DAS in cauliflower; 7 DAS in hyacinth bean and 8 DAS in eggplant and all of the detected quantities were above MRL in three vegetables. According to Prodhan et al. (2018) residue of quinalphos was detected up to 15 DAS in cauliflower; 12 DAS in eggplant; 10 DAS in yard long bean which was longer period of degradation than cypermethrin and the detected residue levels were above MRL up to 10 DAS in cabbage; 7 DAS in eggplant and 5 DAS in yard long bean. The residue of cypermethri was detected up to 7 DAS in yard long bean and tomato and the quantities of residues were above MRL up to 3 DAS in both the vegetables. The results of the present study agreed with the works of the earlier authors.

\section{Conclusions}

The degradation rate of cypermethrin was found faster in brinjal, tomato and cauliflower and slower in all the analyzed vegetables for chlorpyrifos. So, cypermethrin might be the most suitable insecticide for the vegetables which would be harvested at shortest period of time having waiting period of 4 DAS in brinjal and tomato and 5 DAS in cauliflower but in case of chlorpyrifos, vegetables could be harvested at 8 DAS in brinjal and tomato and 10 DAS in cauliflower. The findings of the study will help farmers, consumers and other stakeholders to undertake proper activity for the production of safe vegetables.

\section{Conflict of interest}

None to declare.

\section{Acknowledgements}

The authors are thankful to Pesticide Analytical Laboratory, Division of Entomology, Bangladesh Agricultural Research Institute, Joydebpur, Gazipur for financial assistance to carry out this study.

\section{References}

Agnihotri NP, SN Sinha and AK Chakrabatri, 1990. Bioefficacy of some synthetic pyrethroid insecticides against Leucinodes orbonalis Guen. and their residues in brinjal fruit. Indian J. Ent., 52: 373-378.

Ahmed MS, A Begum and D Sarker, 2020. Determination of pre-harvest interval for dimethoate and quinalphos in selected vegetables. Asian Australas J. Biosci. Biotechnol., 5: 42-47.

Ahmed MS, A Begum, MD Rahman, MW Akon and MAZ Chowdhury, 2016a. Extend of insecticide residue load in vegetables grown under conventional farming in Bangladesh. The Agriculturists, 14: 38-47.

Ahmed MS, A Begum, MDH Prodhan and D Sarker, 2019. Analysis of pesticide residue in vegetables collected from nine different regions of Bangladesh using Gas Chromatography. Asian Australas J. Food Saf. Secur., 3: 23-26.

Ahmed MS, MA Rahman, MDH Prodhan, MW Akon and A Begum, 2016b. Quantification of residue degradation of fenvalerate and acephate in hyacinth bean and tomato under supervised field trial. Asian Australas. J. Biosci. Biotechnol., 1: 284-290.

Ahmed MS, MA Sardar, M Ahmad and KH Kabir, 2018a. Qualitative analysis of insecticide residue in cauliflower samples collected from different regions of Bangladesh. Asian Australas J. Food Saf. Secur., 2: 29-34.

Ahmed MS, MA Sardar, M Ahmad and KH Kabir, 2018b. Detection of the amount of residue degradation rate of six commonly used insecticides in cauliflower under supervised field trial. Asian Australas. J. Food. Saf. Secur., 2: 109-114.

Ahmed MS, MA Sardar, MA Haque and KH Kabir, 2005. A survey on the pattern of insecticidal usage for the protection of the brinjal (Solanum melongena) from the attack of insect pests in Jessore. Bangladesh J. Zool., 33: $57-63$. 
Ahmed, MS, A Begum, MDH Prodhan, M Afroze and D Sarker, 2021. Organophosphorus pesticide residues detected in eggplant and tomato samples collected from different regions of Bangladesh. Asian Australas. J. Food Saf. Secur., 5: 27-31.

Anonymous. 2001. Coordinated research on insecticide residue and resistance in major vegetables grown in Bangladesh. Report on Contact Research Project, BARC, BARI, Joydebpur, Gazipur, 102 p.

Antle JM and PL Pingali, 1994. Pesticides, Productivity and Farmer Health: A Philippine Case Study, American Journal of Agril. Economics, 76: 418-430.

EU pesticides data base. http://ec.europa.eu/food/plant/pesticides/eu-pesticides-data base. Access 10 March 2021.

Gill HK, and H Garg, 2014. Pesticides: Environmental Impacts and Management Strategies. http://dx.doi.org/10.5772/57399

Handa, SK, NP Agnihorti and G Kulshrestha, 1999. Pesticide Residues: Significance, Managment and Analysis, Research Periodicals and book Publishing house, Texas, USA.

Kumar B, VK Madan, J Singh and TS Kathpal, 2004. Monitoring of pesticidal contamination of farm gate vegetables. J. Earth Environ. Sci. Springer Netherlands, 90: 65-71.

Mostafalou S and M Abdollahi, 2012. Concerns of environmental persistence of pesticides and human chronic diseases. Clinical and Experimental Pharmacology, S5: e002. http://dx.doi.org/10.4172/2161-1459.S5-e02.

Nayar, K. K., T. N. Ananthakrishnan and B. V. David. 1995. General and applied Entomology. Eleventh edn. Tata McGraw-Hill Publ. Co. Ltd. 4/12, Asaf Ali Road, New Delhi-110002, 557 p.

O’Brien RD, 1967. Insecticides Action and Metabolism. AP New York, 332 p.

Prodhan MDH, MW Akon and SN Alam 2018. Determination of pre-harvest interval for quinalphos, malathion, diazinon and cypermethrin in major vegetables. J. Environ. Anal. Toxicol., 8: 553.

Rajeswaran J, I Merlin Kamal, S Chandrasekaran, R Jayakumar and S Kuttalam, 2004. Harvest time residue of carbosulfan in brinjal fruits. J. Food, Agriculture and Environment, 2: 276-277.

Rekha, S. and C. P. Mallapur. 2007. Studies on insect pests of Dolichos bean in Northern Karnataka. Karnataka J. Agric. Sci., 20: 407-409.

Riley, D. and S. Sparks. 2008. Common insects affecting cabbage and related cole crops. The University of Georgia College of Agriculture and Environmental Sciences. http:// www.ent.uga.edu/veg/cole crops. htm.

Singh IP and RL Kalra, 1996. Persistence and degradation of Fenvalerate on brinjal. Indian J. Ent. 58: 27-31.

Tejada AW, ED Magallona and EB Lakan-Ilaw, 1983. Insecticide residues in vegetables: Application of the modified approach to organophosphate insecticide residues in string bean (Vigna sesquipedalis Fruw.) Phil. Agr. U. P. Los Banos, 66: 405-416.

Van der Schee HA, 2002. Report of pesticide residue monitoring results of Netherlands. 2001. Inspectorate of Health Protection, Commodities and Veterinary Public Health Food Inspection Service Dee Haag, Amsterdam, Netherlands. 76 p.

Virgina RO and CM Bajet, 1996. Pesticides in the Philippine Environment. In: Proceedings. Anniversary and Annual Scientific Meeting, (Dizon TD, Eusebio JE, Duenas JN, Palis FV and Mabbayad MO eds.). Pest Management Council of the Philippine, Davao City, pp. 61-77.

William H and WL George, 2005. Official Method of Analysis of AOAC International. $18^{\text {th }}$ edn. AOAC International, Gaithersburg, USA, pp.11-75. 